\title{
Effects of Consumption of Soft Drinks on the Muscular Morphology of Animals Submitted to Concurrent Training
}

\author{
Efecto del Consumo de Bebidas Refrescantes en la Morfología \\ Muscular de Animales Sometidos a Entrenamiento Concurrente
}

\begin{abstract}
Paulo Henrique Aleixo ${ }^{1,2}$; Lucas da Silva Santos²; Guilherme Akio Tamura Ozaki ${ }^{3}$; Thiago Alves Garcia ${ }^{3}$; Everton Alex Carvalho Zanuto $^{1}$; Regina Celi Trindade Camargo ${ }^{2}$; José Carlos Silva Camargo Filho ${ }^{2} \&$ Robson Chacon Castoldi ${ }^{1,2,3}$
\end{abstract}

AleiXO, P. H.; SANTOS, L. S.; OZAKI, G. A. T.; GARCIA, T. A.; ZANUTO, E. A. C.; CAMARGO, R. C. T.; FILHO, J. C. S. C. \& CASTOLDI, R. C. Effects of consumption of soft drinks on the muscular morphology of animals submitted to concurrent training. Int. J. Morphol., 37(2):671-676, 2019.

SUMMARY: The consumption of industrialized foods and beverages contributes to the increase in body weight and manifestation of diverse illnesses. Among these industrialized products, soft drinks can be mentioned, which when consumed in large quantities can contribute to weight gain and the emergence of chronic non-communicable diseases such as hypertension, diabetes, and obesity. In terms of performance, several training protocols have been used, among which concurrent training is presented as a tool that can aid in the control of body weight and muscle development. Thus, the identification of dietary factors, as well as the use of appropriate training methods, can be essential factors in the increase in physical performance. To study the effects of concurrent training on the skeletal muscles of animals submitted to soft drink consumption. In the present study, 32 male rats were used, of the Wistar breed, in the post-weaning biological phase (30 days). The animals performed a concurrent training protocol. Forty-eight hours after the final training session, the animals were submitted to a surgical procedure to remove samples of gastrocnemius muscle. After preparation of the histological slides, the muscle fibers of the different groups of animals were measured. The median values for the minimum diameter of muscle fibers presented the following values: Control (C): 35.78, Control Soft Drinks (CSD): 36.93, Training (T): 39.12, and Training Soft Drinks (TSD): 37.82. The CSD and TSD groups demonstrated the greatest increase in body mass in relation to the $\mathrm{C}$ and $\mathrm{T}$ groups. In addition, the groups that performed the concurrent training presented a higher mean of the smallest fiber diameter. It was concluded that the ingestion of soft drinks had a negative effect on the muscular hypertrophy of animals submitted to a concurrent training protocol.

KEY WORDS: Soft drink; Concurrent training; Skeletal muscle.

\section{INTRODUCTION}

In general, the population consumes a lot of empty calories, derived from industrialized foods and beverages, which, associated with a sedentary lifestyle, contribute to an increase in body weight and the manifestation of various illnesses. This set of metabolic and hemodynamic abnormalities is called metabolic syndrome (Ciolac \& Guimarães, 2004).

Among these foods, soft drinks can be mentioned, of which consumption has increased over the years. It is believed that high consumption is related to weight gain and chronic noncommunicable diseases suchas hypertension, diabetes, and obesity, diseases which have become a public health problem (Rombaldi et al., 2011).
Physical activity appears as a factor for prevention and treatment of these diseases. The physiological responses generated by exercise contribute significantly to the composition and decrease in body weight (Machado et al., 2014). Among the models of training, are resistance training that generates muscular adaptations and increased energy expenditure, in addition to preventing obesity, and aerobic training which increases blood flow and strengthens the cardiorespiratory system (Crozeta \& de Oliveira, 2009; Magalhães et al., 2016).

Studies have shown that when the two forms of training are associated, denominated "concurrent training", their efficacy is verified in relation to body composition,

\footnotetext{
${ }^{1}$ Department of Physiotherapy,Paulista State University “Júlio de Mesquita Filho” (Presidente Prudente Campus), Brazil.

${ }^{2}$ Department of Physical Education, Oeste Paulista University, Brazil.

${ }^{3}$ Department of Orthopedy and Traumatology, Campinas State University, Brazil.
} 
gain in muscular mass, and improvement in physical conditioning (Machado et al.).

Thus, the objective of the present study was to analyze the skeletal muscle response of animals submitted to soft drink consumption and to a concurrent training protocol.

\section{MATERIAL AND METHOD}

Animals. In the present study, 32 male rats were used in the post-weaning biological phase (30 days), Wistar breed, obtained from the University of West Paulista Campus - UNOESTE campus II and kept in the small rodent room of the Physiotherapy Department of FCTUNESP, Presidente Prudente Campus - SP (Approval CEUA 004/2016).

The rats were housed in groups of 5 animals per cage (polyethylene), with an ambient temperature of $\left(22+2{ }^{\circ} \mathrm{C}\right)$ and brightness (light/dark cycle of twelve hours), with free access to water and feed (feed for laboratory rats). The study was developed in compliance with the norms and ethical principles of animal experimentation after approval from the Committee on Ethics in Animal Use (CEUA).

Experimental design. The animals were divided into four groups $(n=32)$, control $(C)[n=8]$, control with soft drinks (CR) [ $\mathrm{n}=8$ ], concurrent training (TC) [ $\mathrm{n}=8]$, and concurrent training with soft drinks (TCR) $[\mathrm{n}=8]$.

The animals were submitted to a period of adaptation to the liquid medium and equipment (10-20 min/day, three days per week, for one week, with progressively increasing overload and duration, following the method proposed by Manchado et al. (2006). The adaptation period reduces the stress produced by the liquid medium and the physiological alterations resulting from physical training (Chimin et al., 2009).

\section{Experimental groups}

C Group: The animals remained free in their cages, with unrestricted access to water and feed.

CR Group: The animals remained free in their cages, with unrestricted access to water and feed. However, in this case, a soft drink was added 30 days after birth and maintained for 120 days ( 90 days of hyperglycemia induction +30 days of training), the period corresponding to the end of the experiment.
TC Group: This model of concurrent training was composed of two sessions of different exercises with demands from different energy sources, one predominantly aerobic (swimming) and the other predominantly muscular strength development (jumps).

The aerobic training protocol was composed of three weekly sessions on nonconsecutive days, comprising 30 minutes of swimming exercise, with an intensity of $80 \%$ of the anaerobic threshold (Lan), stipulated from the values established for assessment of the maximum stable phase of blood lactate (Manchado et al.) (Fig. 1). For the aerobic part (swimming), a tank containing cylindrical PVC pipes was used, $25 \mathrm{~cm}$ in diameter and $100 \mathrm{~cm}$ in height, with water to a depth of $70 \mathrm{~cm}$ (Ozaki et al., 2014).

For the strength training protocol (anaerobic), four series of 10 jumps were used, with an overload corresponding to $50 \%$ of the body weight of each animal. For this purpose, a $25 \mathrm{~cm}$ diameter PVC pipe with a height of $38 \mathrm{~cm}$ was used (Fig. 2). The overload was added using a vest specially made for this type of exercise, attached to the anterior torso (Castoldi et al., 2013).

TCR Group: This group was identical to the previous one, but with ingestion of a soft drink. In this case, a soft drink was added 30 days after birth and maintained for 120 days (90 days of hyperglycemia induction +30 days of training), the period corresponding to the end of the experiment.

Prescription of intensity of aerobic training. For the prescription of aerobic training, the value corresponding to the percentage of body weight was used. In this case, the intensity was defined from the results established by Manchado et al. Thus, the threshold intensity corresponding to 5 $\%$ of body weight was established and $80 \%$ of this value was used for aerobic training intensity.

Hyperglycemia induction. Hyperglycemia was induced in the animals, through ingestion of a popular soft drink (guarana type) (Ad libitum). The soft drink is composed of: carbonated water, fructose syrup, caramel dye, phosphoric acid, natural flavorings, caffeine, and low sodium content.

Collection of Tissue Samples. The animals were submitted to the surgical procedure 48 hours after the final exercise session. The samples of the gastrocnemius muscle were obtained according to the methodology described by Águila et al. (1997). The animals were anesthetized with a combination of two anesthetics, ketamine hydrochloride $(70 \mathrm{mg} / \mathrm{kg})$ and xylazine hydrochloride $(15 \mathrm{mg} / \mathrm{kg})$ injected intra-peritoneally as proposed by Seraphim et al. (2001). 

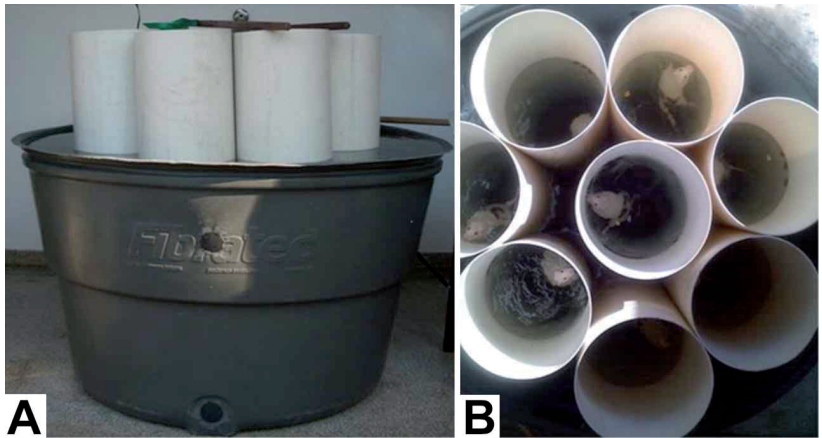

Fig. 1. Illustration of aerobic training in the liquid medium. (A): Cylindrical tubes. (B): Swimming training.

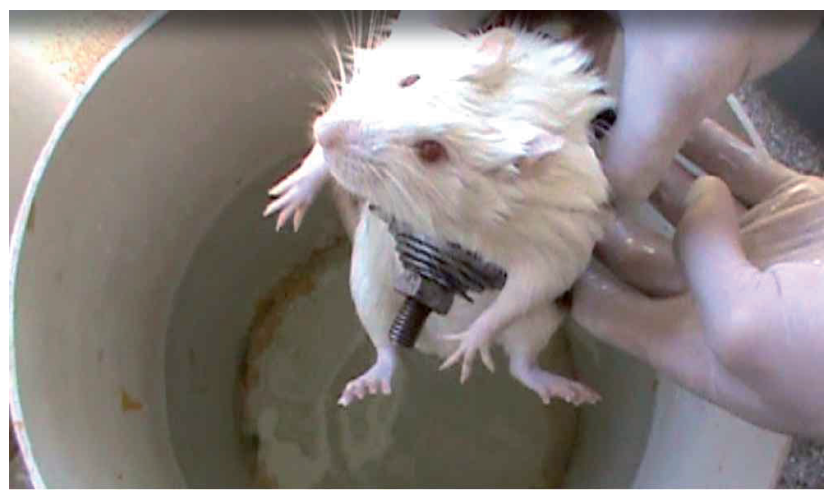

Fig. 2. Illustration of water jump training and apparatus to fix the overload.

Histological Processing of Skeletal Striated Muscle. The muscle tissue was immersed in n-hexane cooled in liquid nitrogen through the freezing of unfixed tissues method, and later stored in an ultra-low temperature freezer $\left(-80^{\circ} \mathrm{C}\right)$. The $5 \mathrm{~mm}$ sections were produced in a cryostat microtome at $-20{ }^{\circ} \mathrm{C}$, collected on slides and then stained with hematoxylin-eosin (HE) for general analysis of the structure.

\section{Analysis of Muscle Tissues}

Optical microscopy. The sections were submitted to staining and histochemical reactions and were observed in normal light and photomicrographed under a Nikon ${ }^{\circledR}$ microscope, model H550S. A photographic camera Infinity 1 was used to analyze the images. The interactive markers, to determine the mean of the smallest diameter of muscle fibers, were performed using the software (AuxioVisionRel 4.8 - Carl Zeiss and NIS-Elements D3.0 - SP7 - Nikon $\left.{ }^{\circledR}\right)$. In total, 100 muscle fibers were observed on each slide, according to the protocol established by Dal Pai Silva (1995).

Statistical analysis. After obtaining the data, the following tests were performed: Shapiro-Wilks for normality; Kruskal Wallis or ANOVA to verify the difference between pre- and post-training moments; Dunn or Tukey post-test to verify the difference between groups. All procedures assumed the error of $5 \%(\mathrm{p}<0.05)$.

\section{RESULTS}

Analysis of body mass demonstrated that all groups presented increased body mass, however, the CR and TCR groups presented higher values for this variable (Fig. 3).

From the images of the muscle fibers, different morphologies were observed between each of the groups (Fig. 4). In addition, indications of inflammatory infiltrate were verified in the groups of trained animals (TC and TCR).

After measurement of the muscle fibers, median values were verified for the minimum diameters of 35.78 ; 36.93 ; 39.12; and $37.82 \mathrm{~mm}$, for the groups C, CR, TC, and TCR, respectively (Fig. 5).

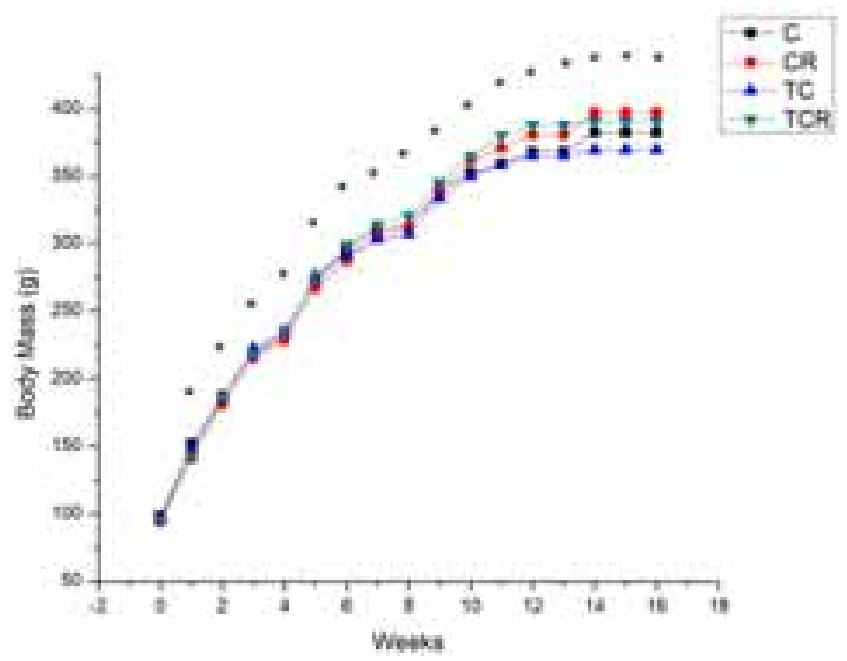

Fig. 3. Evolution of body mass between different groups of animals. (C): Control Group. (CR): Soft Drink Control Group. (TC): Training Group. (TCR): Soft Drink Training Group. ANOVA for repeated measures with the Bonferroni post test. (*): Statistically significant differences ( $p<0.05)$.

\section{DISCUSSION}

The objective of the present study was to analyze the effects of the consumption of soft drinks on the skeletal striated musculature of animals submitted to a concurrent training protocol. It was verified that the response to the concurrent training was an increase in the mean of the smallest diameter in the trained animals, independent of the consumption of a soft drink. However, the group that consumed the soft drink demonstrated a lower mean when compared with the animals that did not consume the soft drink. 

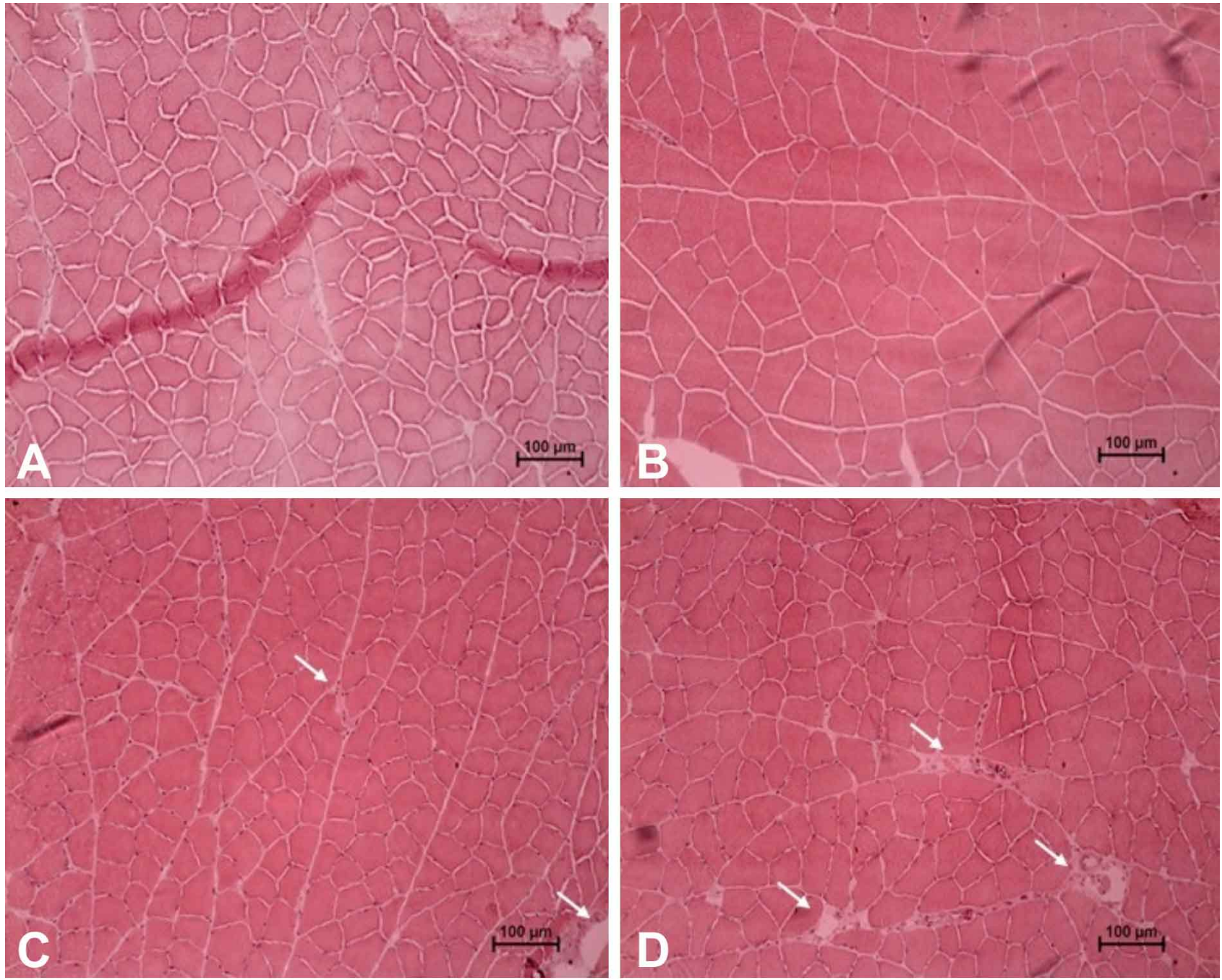

Fig. 4. Morphology of the muscle fibers of Wistar rats. Hematoxylin and Eosin stained sections with 10x magnification. Arrows indicate the presence of inflammatory infiltrate. (C): Control Group. (CR): Soft Drink Control Group. (TC): Training Group. (TCR): Soft Drink Training Group.

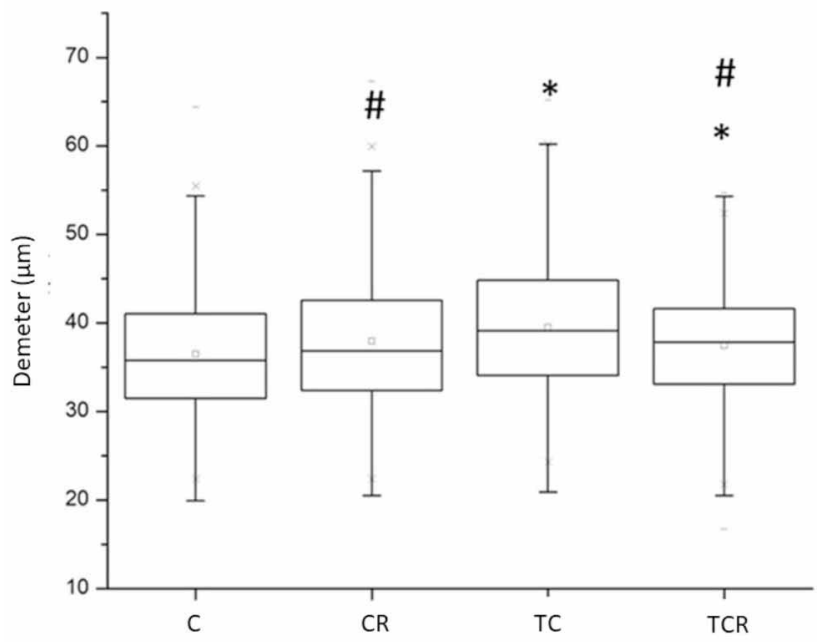

Fig. 5. Median values in relation to the smallest diameter between the different groups of animals. (C): Control Group. (CR): Soft Drink Control Group. (TC): Training Group. (TCR): Soft Drink Training Group. Kruskal-Wallis test with significance of $5 \%$ (p $<0.05)$. (*) Difference compared to the control group. (\#): Difference compared to the T groups. 
In their findings, Rombaldi et al. claim that soft drink consumption is associated with increased body weight and obesity. In addition, there are few studies that affirm this hypothesis, mainly in animals.

Another factor observed was that the rats that consumed soft drinks had lower feed intake. In this case, the decrease in feed consumption may have contributed to a decrease in the lean muscle mass of the animals.

The decrease in protein coming from the diet could be related to lower absorption of proteins and nutrients, and may cause a decrease in the muscle mass of the trained rats, since their energy expenditure was higher than the control group. Morais et al. (2008) make it clear in their study that a combination of proteins and other nutrients can generate significant gains in strength and gains in muscle mass.

With regard to the training methodology, Castoldi et al. (2013) and Machado et al., showed in their studies that concurrent training can generate muscle mass gains and improvement in body composition. However, in these cases, the authors did not use soft drinks as an additive in the diet of the animals.

There seems to be evidence that when used $3 \mathrm{x} /$ week, concurrent training is capable of generating increased physical capacity, in particular, promoting muscle hypertrophy. Published studies using this training methodology demonstrated significant increases in the crosssectional area and smallest diameters of the muscle fibers of rats, both in aquatic environments and soil exercises, with normal and hypercaloric diets (Castoldi et al., 2013; Machado et al.; Castoldi et al., 2017).

In addition, on another occasion, concurrent training with or without beta-hydroxy-beta-methylbutyrate (HMB) supplementation was tested. In the latter case, it was verified that animals that performed concurrent training without supplementation demonstrated no decrease in muscle mass (Araújo et al., 2017).

Thus, the aforementioned studies contradict the "concurrent" theory originally proposed by Hickson (1980), who verified an increase in physical capacities generated by performing concurrent training. It is worth mentioning that the study of Hickson (1980) included athletes of both sexes, who performed the muscular and aerobic strength training for 5 or 6 days/week, for a period of 10 weeks, with high intensities and only one weekly rest break. In the present study, Wistar rats were used, with a training frequency of $3 \mathrm{x} /$ week, at intensities of $50 \%$ of body weight for strength training and $80 \%$ of anaerobic threshold intensity, for a period of 4 weeks.
Thus, the present study collaborates with the literature in investigating the effects of ingestion of a soft drink added to performance of a concurrent training protocol. However, there are some limitations of the study related to the quantification of protein intake. In addition, protein quantification as well as analysis of gene expression may contribute to the results obtained to date.

\section{CONCLUSION}

It was concluded that the ingestion of a soft drink had a negative effect on the muscular hypertrophy of animals submitted to a concurrent training protocol.

ACKNOWLEDGMENTS. The authors are grateful to the Brazilian Agency of Resources for Higher Education Personnel (CAPES), National Advice for Scientific and Technological Development (CNPq), Program of Scientific and Technological Initiation (PIBIC), and the Physical Therapy Department and Post Graduate Program in Physical Therapy for supporting the development of this study.

ALEIXO, P. H.; SANTOS, L. S.; OZAKI, G. A. T.; GARCIA, T. A.; ZANUTO, E. A. C.; CAMARGO, R. C. T.; FILHO, J. C. S. C. \& CASTOLDI, R. C. Efecto del consumo de bebidas refrescantes en la morfología muscular de animales sometidos a entrenamiento concurrente. Int. J. Morphol., 37(2):671-676, 2019.

RESUMEN: El consumo de alimentos y bebidas industrializadas contribuyen al aumento de peso corporal y manifestación de diversas enfermedades. Entre estos alimentos, se encuentran las bebidas refrescantes, que al ser consumidas en grandes proporciones, pueden contribuir al aumento de peso y a la aparición de enfermedades crónicas, tales como la hipertensión, diabetes y obesidad. En cuanto al desempeño, diversos protocolos han sido utilizados, entre estos, el entrenamiento concurrente que puede ser una forma de ayuda en el control de peso corporal y el desarrollo muscular. Siendo así, la identificación de los factores alimentarios, como también la utilización de los métodos correctos de entrenamiento, pueden ser esenciales en el aumento del desempeño físico. El objetivo del estudio fue investigar los efectos del entrenamiento concurrente en la musculatura esquelética de animales sometidos al consumo de bebidas refrescantes. En la presente investigación fueran utilizadas 32 ratas Wistar. Los animales fueran sometidos a un protocolo de entrenamiento concurrente. Después de 48 horas de la última sesión de entrenamiento, los animales fueran sometidos a un proceso quirúrgico para la remoción de muestras de tejido muscular. Los valores de la media del diámetro de las fibras musculares fueron: Control (C): 35,78; Control y Bebida Refrescante (CBR): 36,93; Entrenamiento (ET): 39,12; y Entrenamiento y Bebida Refrescante (EBR): 37,82. Se observó que los grupos CBR y EBR presentaron mayor aumento de masa cor- 
poral en comparación con C y T. Además, los grupos que realizaran el entrenamiento concurrente obtuvieron una mayor media en el diámetro de las fibras. Es posible concluir que el consumo de bebidas refrescantes tiene una influencia negativa en la hipertrofia muscular de animales sometidos a un protocolo de entrenamiento concurrente.

PALABRAS CLAVE: Bebidas refrescantes; Entrenamiento concurrente; Musculo esquelético.

\section{REFERENCES}

Águila, M. B.; Apfel, M. I. R. \& Mandarim-de-Lacerda, C. A. Comparação morfológica e bioquímica entre ratos envelhecidos alimentados com dieta hiperlipídica e com óleo de canola. Arq. Bras. Cardiol., 68(3):15561, 1997.

Araújo, R. G.; Castoldi, R. C.; Dos Santos, C. C.; Machado, J. H. L.; Ozaki, G. A. T.; Garcia, T. A.; Teixerira, G. R.; Camargo Filho, J. C. S. \& Papoti, M. Effects of HMB supplementation on body composition of rats. Int. J. Morphol., 35(2):705-10, 2017.

Castoldi, R. C.; Aleixo, P. H.; Pereira, A. C. J.; Ferreira, S. R.; Garcia, T. A.; Ozaki, G. A. T.; Koike, T. E.; Pinto Júnior, D. A. C.; Seraphim, P. M.; Belangero, W. D. \& Camargo Filho, J. C. S. Effects of concurrent training on muscle fibers of Wistar rats submitted to standard and hypercaloric diets. Int. J. Morphol., 35(2):637-43, 2017.

Castoldi, R. C.; Camargo, R. C. T.; Magalhães, A. J. B.; Ozaki, G. A. T.; Kodama, F. Y.; Oikawa, S. M.; Papoti, M. \& Camargo Filho, J. C. S. Concurrent training effect on muscle fibers in Wistar rats. Mot. Rev. Educ. Fis., 19(4):717-23, 2013

Chimin, P.; Araújo, G. G.; Manchado-Gobatto, F. B. \&Gobatto, C. A. Critical load during continuous and discontinuous training in swimming Wistar rats. Motricidade, 5(4):45-58, 2009.

Ciolac, E. G. \& Guimarães, G. V. Exercício físico e síndrome metabólica. Rev. Bras. Med. Esporte, 10(4):319-24, 2004

Crozeta, C. \& de Oliveira, G. K. Análise do perfil alimentar de mulheres com sobrepeso, praticantes de treinamento de força em academias de Curitiba-PR. Rev. Bras. Nut. Esportiva, 3(17):432-41, 2009.

Dal Pai Silva, M. Histoenzimologia: Teoria e Prática. Botucatu, Instituto de Biociências, Universidade Estadual Paulista, 1995.

Machado, J. H. L.; Horie, G. M.; Castoldi, R. C.; Camargo, R. C. T. \& Camargo Filho, J. C. S. Efeito do treinamento concorrente na composição corporal e massa muscular de ratos Wistar. Rev. Bras. Cienc. Mov., 22(3):34-42, 2014.

Magalhães, A. J. B.; Castoldi, R. C.; Camargo, R. C. T.; Ozaki, G. A. T.; Costalonga, R. R.; Moreira, R. J. \& Camargo Filho, J. C. S. Seraphim, P. M. Can the intermittent training generate alterations on the liver tissue of rats submitted to a hyperlipidic diet? Int. J. Morphol, 34(1):906, 2016.

Manchado, F. B.; Gobatto, C. A.; Contarteze, R. V. L.; Papoti, M. \& Mello, M. A. R. The maximal lactate steady state is ergometer-dependent in experimental model using rats. Rev. Bras. Med. Esporte, 12(5):25962, 2006.

Morais, R.; Medeiros, R. R. \& Liberali, R. Eficácia da suplementação de proteínas no treinamento de força. Rev. Bras. Nut. Esportiva, 2(10):26576, 2008.

Ozaki, G. A. T.; Koike, T. E.; Castoldi, R. C.; Garçon, A. A. B.; Kodama, F. Y.; Watanabe, A. Y.; Job, A. E.; Louzada, M. J. Q.; Camargo, R. C. T. \& Camargo Filho, J. C. S. Efeitos da remobilização por meio de exercício físico sobre a densidade óssea de ratos adultos e idosos. Motricidade, 10(3):71-8, 2014

Rombaldi, A. J.; Neutzling, M. B.; da Silva, M. C.; Azevedo, M. R. \& Hallal, P. C. Factors associated with regular non-diet soft drink intake among adults in Pelotas, Southern Brazil. Rev. Saúde Pública, 45(2):382-90, 2011

Seraphim, P. M.; Nunes, M. T. \& Machado, U. F. GLUT4 protein expression in obese and lean 12-month-old rats: insights from different types of data analysis. Braz. J. Med. Biol. Res., 34(10):1353-62, 2001.

Corresponding author:

Prof. Dr. Robson Chacon Castoldi

Professor do Departamento de Educação Física pela

Universidade do Oeste Paulista - UNOESTE

Doutor em Ciências da Cirurgia pela Universidade Estadual de Campinas - UNICAMP

Membro do Laboratório de Análise da Plasticidade Muscular - LAPMUS pela Universidade Estadual Paulista "Júlio de Mesquita Filho" - UNESP.

São Paulo

BRAZIL

Email:castoldi_rc@yahoo.com.br

Received: 11-10-2018

Accepted: 14-01-2019 